\title{
OFFICIAL NAMING IN HÅ, KLEPP AND TIME
}

\author{
INGE S R RHEIM \\ University of Stavanger
}

ABS TRACT

Toponyms localize, reflect and give information about historical traditions and various phenomena in an area. They form part of the local heritage and culture. The relationship between place names, heritage and identity is often underlined in guidelines regarding official naming of streets and roads. In what way is heritage and local identity reflected in the road names of the three municipalities Hå, Klepp and Time (Southwest-Norway), and how is the special character of this area expressed in the names?

More than half of the official road names in the three municipalities are either identical with a local toponym, or they consist of a word for 'road' and a local toponym (or an appellative describing the location). This shows that there is a strong commitment to base the official naming on local tradition and thus contribute to identity. Quite a few elements from the dialect, e.g. special pronunciation, grammatical forms or local words, appear in the names, especially in the road names from Hå, reflecting that the names are part of the local culture, and due to the fact that the dialect is unique. Consistency is a challenge, however; the same word is sometimes spelled in different ways in different names. It appears that, with some exceptions, cultural heritage and local tradition have been preferred principles and guidelines with regard to naming of roads in the three municipalities, due to a consciousness that heritage and tradition create identity.

\section{[1] LOCAL TRADITION AND IDENTITY}

The main function of place names is to identify places or locations. The names serve as addresses or address markers in oral and written communication. The use of toponyms makes it possible to localize activities and various phenomena in the daily conversation and in a written text. Place names are links to the past. They form part of our local heritage and culture. Toponyms localize, reflect and give information about historical traditions, activities, events and various phenomena in an area. They also contain important information about the local language, the dialect. Place names are therefore valuable sources for researchers and students, especially for linguists, historians and archaelogists (Særheim 2004).

The link between cultural heritage and memory on the one hand and identity on the other has in recent time been emphasized by researchers as well as town planners. Some researchers take the view that collective identity and cultural 
memory have become important due to an identity crisis in the post-modern era (Bauman 2000; Krogseth 2007). Dissemination of our cultural heritage is a necessary base for identity.

The relationship between place names, cultural heritage and local identity is often underlined in guidelines and regulations regarding official naming of streets and roads in towns and cities. Official naming is different from common naming of places. Toponyms are normally made by common people living in an area in connection with working processes and daily life, reflecting local traditions, whereas official street and road names are decided by politicians, reflecting their values and preferences (Særheim 2008, 66 pp.).

\section{[2] OFFICIAL NAMING IN HA, KLEPPAND TIME}

In what way is cultural heritage and local identity reflected in the official road names of the three municipalities Hå, Klepp and Time in Jæren (Southwest-Norway), and how is the special character of the area expressed in the names, with regard to historical development, culture, mentality and language? In this context it is relevant to study the linguistic content and form of the names, as well as the values that the politicians intend to promote through the official naming.

The Jæren district is productive farm land. There has been continuous farming in this area for more than 4000 years. Nowadays the area is also heavily industrialized, ranging from traditional farming industry to modern oil industry. There are approx. 16000 inhabitants in each of the three municipalities. The major towns are Bryne (9 000 inhabitants, Time), Nærbø (Hå) and Kleppe (Klepp), the two first-mentioned being so-called "stasjonsbyar" (towns with a railway station); they expanded rapidly after the opening of the local railway, Jærbanen, in 1878. The official road name registers contain approx. 270 names from Time, 245 from Klepp and 310 from Hå.

In the guidelines regarding official naming of roads and streets in Time there is a strong recommendation to use old place names from the area, toponyms that are known and used by people who live there: "Ta vare på lokale stadnamn som er i bruk/har vore i bruk på folkemunne [...] Ein bør helst velja gamle namn". The importance of using names that create identity is emphasized: "Identitetsberande namn vil vera ein ressurs for staden". Similar naming principles are followed in Hå and Klepp.

\section{[3] USING A LOCAL PLACE NAME}

More than half of the official road names in the three municipalities are either identical with a local place name, or they consist of a word for 'road' and a local toponym (or an appellative describing the location). Examples of road names that are identical with a local toponym are Kjøpmannsbrotet ('the tradesman's hill'; 
Klepp), Nubben ('the small hill'; Time), Auren (an area with 'gravel'; Hå), Påskevarden (a top where people used to meet on Easter Eve to watch "the moon dance"; Hå), Elisberget ('the hill of Elias'; Hå), Helmikhølen (a deep pool in a river, probably where Helmik used to fish; Hå) and Ævestvollmarka (uncultivated field belonging to the farm Ævestvoll; Hå).

Road names like Longholsvegen (Longholen 'the long hill'; Klepp), Mcrbakkvegen (Morbakken 'the hill by the fish traps'; Klepp), Lonarmyrvegen (Lonarmyra 'the bog by the deep pool'; Time) and Grønholsvegen (Grønholen 'the green hill'; Hå) contain a word for 'road' (veg) and a compound local toponym, whereas Livegen ('the road alongside the slope', li; Klepp), Dalvegen ('the road in the valley', dal; Hå) and Tjødnavegen ('the road by the pond', tjørn; Time) contain a word for 'road' (veg) and an appellative (or an uncompounded name with that appellative) describing a nearby location.

These road names are made in the same way as normal place names from the district. The names contain information about topography, fauna, flora, farming, hunting, fishing, travel, administration, defence, religion, special traditions, phenomena and events. This way of naming is in accordance with the recommendation to use toponyms that already exist in the area. It shows that there is a strong commitment to base the official naming on local tradition and culture and thus contribute to local identity.

In the naming principles of the neighbouring municipalities Stavanger and Sandnes, the first mentioned a mediaeval city, there is also a strong recommendation to use place names that already exist in the area when naming new streets (Særheim 2008). Still there are fewer existing toponyms per cent among the official street and road names in Stavanger and Sandnes than in Hå, Klepp and Time.

\section{[4] GROUP NAMING}

Approx. $20 \%$ of the road names in the three municipalities represent so-called group naming. The road names in an area contain similar semantic elements, words for plants, birds, wild animals, stones etc., e.g., Einervegen ('juniper'; Time), Neslevegen ('nettle'; Hå), Kråkevegen ('crow'; Hå), Ekornvegen ('squirrel'; Klepp), Elgvegen ('elk'; Time), Rubinvegen ('ruby'; Time). Normally these names have no special link to traditions or characteristic features in the area, even though the mentioned plants and animals often appear in the district. In this case new names have been constructed, sometimes instead of using the toponyms that already existed in the area.

It has been argued that it is easier for the ambulance, fire squad and police to find the right locations when the road names have similar semantic content. However, a new problem is created, because quite a few of the names are found in more than one town. The major towns in Jæren are quite close and the municipalities are fairly small (Klepp $115 \mathrm{~km}^{2}$, Time $182 \mathrm{~km}^{2}$, Hå $255 \mathrm{~km}^{2}$ ). Also other 
municipalities in this district are close and most of them are small: Sola $\left(69 \mathrm{~km}^{2}\right)$, Stavanger $\left(70 \mathrm{~km}^{2}\right)$, Randaberg $\left(25 \mathrm{~km}^{2}\right)$. However Sandnes $\left(303 \mathrm{~km}^{2}\right)$ and Gjesdal $\left(609 \mathrm{~km}^{2}\right)$ are larger.

Several names, e.g., Fiolstien ('violet'), Furuvegen ('pine'), Kløvervegen ('clover'), Lyngvegen ('heather'), Erlevegen ('wagtail'), Lerkevegen ('lark') and Vipevegen ('lapwing') appear in all three municipalities (i.e. Hå, Klepp and Time). Most of them are also found in one or more of the mentioned neighbouring municipalities. A number of identical road names appear in two different towns in the three municipalities: Asalvegen ('beam'; Hå, Time), Bjørkevegen ('birch'; Hå, Time), Granvegen ('spruce'; Hå, Time), Konvallvegen ('lily of the valley'; Hå, Time), Liljevegen ('lily'; Klepp, Time), Poppelvegen ('poplar'; Hå, Time), Porsvegen ('bog myrtle'; Hå, Time), Rosevegen ('rose'; Klepp, Time), Røsslyngvegen ('heather'; Klepp, Time). Many more examples could be added to this list.

A special type of group names are found in Hå where some roads are named after tools and equipment used in traditional farming: Greipvegen, Hakkevegen, Rivevegen, Sigdvegen, Spadevegen, Plogvegen, Grimevegen, Kjerrevegen and Vognvegen, referring to 'manure fork' (greip), 'pickaxe' (hakke), 'rake' (rive), 'sickle' (sigd), 'spade' (spade), 'plough' (plog), 'halter' (grime), 'cart' (kjerre) and 'wagon' (vogn).

In Klepp some roads are named after working methods and traditions within farming, especially haying and cutting peat: Høyvegen, Slattevegen, Hesjevegen, Torvvegen and Stakken, referring to 'hay' (høy), 'haymaking' (slåtte), 'hay-drying rack' (hesje), 'peat' (torv) and 'rick of hay' (stakk). Names reflecting traditional labour and working methods within farming may contribute to consciousness of the past and creation of local identity, even though the names are constructed and do not contain a local toponym. .

\section{[5] LOCAL ACTIVITIES AND TRADITION}

In an old city, like Stavanger, a number of street names refer to local activities and traditions --- communication, travel and transport, old handicraft and trade, shipping industry, old town life and culture, e.g., Tjodveien (an old road for common 'people'), Laberget (a rock by the sea where one used to load and unload the goods), Rosenkildegata (contains the name of an old trade firm, The House of Rosenkilde), Høkkergata ('hucksters, hawkers'), Verven ('shipyard'), Banevigsgata ('ropery'), Skansegata (refers to the old battery of the harbour), Misjonsveien (site of the oldest Norwegian missionary organization), Kannikgata (linked to the property of the canons of the city's cathedral, St. Svithun's church, built in the 1120s). These street names reflect different stages of the development of the city (Særheim 2008, 68 pp.; Berntsen 1939).

In the fairly young towns of Hå, Klepp and Time considerably fewer names refer to local industry, handicraft etc., and fewer areas are covered; most of the names are linked to farming industry. Examples are Industrivegen ('industry'; Hå, 
Klepp) and Industrigata (Hå), Bedriftsvegen ('factory'; Klepp, Time), Nceringsvegen ('nourishment, food'; Hå), Meierigata ('dairy plant'; Hå, Time), Smiegata (Time) and Smievegen ('forge, smithy'; Hå, Klepp), Trelastvegen ('timber'; Hå), Isvegen (ice cream factory; Klepp), Plogvegen (a factory where ploughs were manufactured; Klepp), Møllevegen ('mill'; Hå), Kvednavegen (Hå), Kvernbakken (Time) and Kvednadalen ('corn-mill'; Klepp).

It must be added though that a number of the local place-names that are used as official road names reflect labour, activities and tradition in the area, most often in connection with traditional farming, e.g., Aurbanen ('gravel pit'; Hå, Klepp), Smedabråtet ('blacksmith'; Hå), Geilane ('cattle track'; Time), Torget ('market place'; Time), Kjeldevegen ('spring'; Time), Mcerbakkvegen ('fish trap'; Klepp), Kjengaren (a place with a special type of haystack; Klepp).

\section{[6] MEMORIAL NAMES}

$12 \%$ of the road names in Time, 6 \% in Klepp and 0,7 \% in Hå are so-called memorial names; the roads are named after people who have had an important position in one way or another. Most of the persons mentioned are men, $93 \%$ in Klepp, 74 \% in Time, 50 \% in Hå. The persons chosen illustrate the values among people in important political positions. Nearly all of the persons represented come from the municipality. A few exceptions are found in Time, e.g., Roald Amundsens veg (Norwegian polar explorer) and Erling Skjalgssons veg (a Viking chief from a neighbouring municipality, Sola).

Some streets in Bryne are named after royalty, Norwegian kings and queens, e.g., Kong Haakons veg and Dronning Mauds gate. Also mediaeval kings and queens are represented: Kong Sverres gate, Kong Sigurds gate, Kong Magnus' gate, Kong Haralds gate, Olav Kyrres gate, Dronning Astrids gate, Dronning Ingrids gate. Even Snorres gate (Snorri Sturluson, mediaeval historian from Iceland) appears in Bryne, maybe reflecting that Bryne has been a centre of education and culture for some generations; a so-called "landsgymnas" (district high-school) was established here in 1922.

Personal names in fiction are represented in Veslemøyvegen and Haugtussavegen, containing the name of a literary figure in Arne Garborg's well known cycle of poems Haugtussa. Both road names are found in Time, where Garborg was born and grew up, as well as in Hå. In Bryne one also finds Arne Garborgs veg and Hulda Garborgs veg, the last-mentioned named after his wife, who was also a well-known author. Theodor Dahls veg, named after an author from Klepp, appears in both Klepp and Time.

In Stavanger approx. $23 \%$ of the street names, altogether 390 names, are memorial names (Særheim 2008, 75 pp.). $13 \%$ of them (i.e. 50 street names) contain the name of a woman. Approx. $35 \%$ of the men and $26 \%$ of the women mentioned in these names have had a strong link to the Stavanger region. Quite a few 
of the persons belong in other words to the national scene, e.g., Oscar Mathisens gate (speedskater), Lalla Carlsens gate (actress), Amalie Skrams gate (author), and a few of them to the international scene, Robert Scotts gate (English polar explorer), Ellsworths gate (American polar explorer). The persons chosen represent arts and culture, science, education, politics, business, sports, social life, the royal family and mediaeval history.

\section{[7] THE LOCAL DIALECT}

Quite a few elements from the local dialect appear in the official road names in the three municipalities. This is a result of the dialect movement in Norway, which started in the early 1970s, and the growing understanding of the relationship between place names and local identity. Elements from the dialect reflect that the names are part of the local culture. They represent continuity as well as individuality, due to the fact that the dialect is unique. Some typical local words are used, e.g., Gjegnet ('the shortcut'; Hå), Aurbanen ('the gravel pit'; Hå, Klepp), Kjelvene ('the meadows'; Klepp), Kjengaren (a place with a special type of haystack; Klepp), Foren ('wet piece of land'; Time), Floen ('the puddle'; Time).

In several road names from Hå some special grammatical forms in the dialect are used, e.g., definite feminine nouns ending in $-a$ (instead of $-a$, which is the national standard): Klemmå (klemme 'squeeze, trap') Alvalia (li 'hillside'), Breidengjå (eng 'meadow'), Leirmyrå (myr 'bog'), Nygårdsidå (side 'side'). Other feminine nouns are written in accordance with the national norm, e.g., Blåbcrtua (tue 'tuft, mound'), Langgata (gate 'street'), Ævestvollmarka (mark 'uncultivated field'), which may be regarded as inconsistent.

In some cases the same word has even got different endings (spellings) in different names: Roskliä-Bølia (li), Bjorhaugslettå-Rosksletta (slett(e) 'plain'), all of them from Hå. In the names from Klepp and Time - $a$ is normally used in feminine nouns. Exceptions are Rudlå (rulle 'hill, mound') and Stølslogå (lege 'plain where the cows used to lie'), both from Time. Names containing definite form of the neuter noun hall 'slope' is written in three different ways in Nordhallet, Roskhadle and Brattlandshadlet, all of them from Hå.

In some road names, especially from Hå, pronunciation typical for the dialect but different from the national norm is reflected in the spelling of the names: Nordra Subagata (suppe 'soup'), Smedabråtet (brot 'hillside'), Storcegrå (ekre 'meadow'), Djuphodl (hol 'hill, mound'), Roskhadle (hall 'slope'), Kvednavegen (kvern 'mill'), Sannarvågen (sand 'sand'). Examples are also found in Klepp and Time: Tjødnavegen (tjørn 'small lake'; Time), Sandhodlsvegen (hol 'hill, mound'; Klepp), Kvednadalen (kvern; Klepp), Kvednalandsbakken (kvern; Time). Names from Klepp and Time are, however, most often written in accordance with the national norm: Brotet (brot 'hill'; Klepp), Kolleholen (hol 'hill, mound'; Klepp), Røyrvika (vik 'bay'; Time). Consistency is a problem; the same word is sometimes spelled in different ways in 
different names: Storcegrå-Ekrevegen (ekre 'meadow'; Hå), Djuphodl-Kviholen (hol 'hill, mound'; Hå), Sannarvågen-Sandhelleren (sand; Hå), Vodlavegen-Vollvegen (voll 'meadow'; Klepp), Kvednalandsbakken-Kvernelandsvegen (kvern 'mill'; Time).

Elements from the local dialect are also found in official spellings of street and road names from Stavanger and Sandnes (Særheim 2008, 78 pp.). Some of the spellings are not in accordance with the national norm, e.g., Valbergjet (berg(et) 'mountain, rock'), Ulvaryggjen (rygg(en) 'back, ridge'), Vodlaveien (voll 'meadow'), Bjødnabeen (bjørn 'bear', bede 'small piece of land'), Sandalsloen (Sanddalslunden; sand, dal 'valley', lund 'grove'), Madlatuå (tue 'hillock'). Consistency is a challenge, however; sometimes the same word is written in different ways in different names: Kvednabergjet - Kvernevik (kvern 'mill'), Vibemyr - Vipeveien (vipe 'lapwing'), Hatleveien - Hasselveien (hassel 'hazel'). A similar ending has also been written in different ways: Langgata - Sandgåda, containing definite form of the related words gate 'street' and gote 'road, path'.

Quite a few farm names (especially from Klepp and Time) are neither composed in accordance with the dialect nor spelled according to the national norm, but identical with the same name used as a surname: Rosselandsvegen (Time), Reeholen (Time), Grudevegen (Klepp), Øgårdsvegen (Klepp), Øksnevadvegen (Klepp), Hattelandsvegen (Klepp), Grødelandsvegen (Klepp), Stangelandsvegen (Klepp), Uelandsgata (Hå), referring to the farms Rossaland, Re, Gruda, Øydgard, Øksnavad, Hattaland, Grødaland, Stangaland and Ualand (Særheim 2007, 81 p., 90, 181, 188, 215 p., 244 f., 265, 269).

The same farm name is sometimes spelled in two different ways: Skjerpevegen - Skjorpebakken (Skjerpe; Hå), Ualand - Uelandsgata (Ualand; Hå), Kvernelandsvegen - Kvednalandsbakken (Kvernaland; Time), (Særheim 2007, 136, 204, 244 p.). An old spelling principle is reflected in Skandsabakken (Hå), containing the word skanse masc. 'entrenchment', evidently because of the spelling of the surname Skandsen.

\section{[8] CONCLUSION}

It appears that, with some exceptions, cultural heritage and local tradition have been preferred principles and guidelines with regard to official naming of roads and streets in the three municipalities, due to a consciousness that cultural heritage and tradition create identity. The link to the past and the local culture is strengthened by the fact that approx. half of the official road names include a traditional toponym from the area. The cultural aspect also applies to the linguistic form of the names. Characteristic elements from the local dialect are included to show that the names are unique and part of the inherited local culture, even though this in many cases has created problems with regard to consistency in the road name material and accordance with the national norm and law on place names in official use. 


\section{REFERENCES}

Bauman, Z. 2000. Liquid Modernity. Oxford: Blackwell.

Berntsen, M. 1939. Stedsnavn i Stavanger by og noermeste omegn [Place-names in Stavanger and its neighbourhood]. Stavanger: Stabenfeldts forlag.

Krogseth, O. 2007. Navn og kollektiv identitet [Names and collective identity]. Nytt om namn 46. 59-63.

Særheim, I. 2004. Toponymy and teaching: cultural history and cultural experience. Onoma 39. 217-241.

Særheim, I. 2007. Stadnamn i Rogaland [Place names in Rogaland]. Bergen: Fagbokforlaget.

Særheim, I. 2008. Urbane namn og kulturell identitet [Urban names and cultural identity]. Namn og Nemne 24. 65-81.

AUTHOR CONTACT INFORMATION

Inge Særheim

University of Stavanger

Department of cultural studies and languages

N-4036 Stavanger

Norway

inge.saerheim@uis.no 